\title{
Adrenal Cancer TNM Finding v7
}

National Cancer Institute

\section{Source}

National Cancer Institute. Adrenal Cancer TNM Finding v7. NCI Thesaurus. Code C89396.

A finding about one or more characteristics of adrenal cancer, following the rules of the TNM AJCC v7 classification system. 